\title{
Synthesis and characterization of $\mathrm{BiOCl}-\mathrm{Cu}_{2} \mathrm{ZnSnS}_{4}$ heterostructure with enhanced photocatalytic activity
}

\author{
Arpita Paul Chowdhury ${ }^{1} \cdot$ Baban H. Shambharkar ${ }^{1}$
}

Received: 13 April 2018 / Accepted: 11 October 2018 / Published online: 19 October 2018

(c) The Author(s) 2018

\begin{abstract}
$\mathrm{Cu}_{2} \mathrm{ZnSnS}_{4}$ QDs (5-7 nm) were synthesized by chemical coprecipitation route. Using prepared $\mathrm{Cu}_{2} \mathrm{ZnSnS}_{4}$ QDs, a new type of $\mathrm{BiOCl}-\mathrm{Cu}_{2} \mathrm{ZnSnS}_{4}$ heterostructures were prepared using bismuth nitrate as a precurssor and potassium chloride as a source of chlorine at $100{ }^{\circ} \mathrm{C}, 4 \mathrm{~h}$. BiOCl- $\mathrm{Cu}_{2} \mathrm{ZnSnS}_{4}$ heterostructures were analyzed by XRD, TEM, UV-visible NIR, $\mathrm{PL}$ and surface area studies. The diffracted peaks of $\mathrm{BiOCl}-\mathrm{Cu}_{2} \mathrm{ZnSnS}_{4}$ heterostructure show the presence of tetragonal $\mathrm{BiOCl}$ and did not show the intense peaks of $\mathrm{Cu}_{2} \mathrm{ZnSnS}_{4}$ QDs. TEM images of BiOCl- $\mathrm{Cu}_{2} \mathrm{ZnSnS}_{4}$ showed the deposition of $\mathrm{Cu}_{2} \mathrm{ZnSnS}_{4}$ QDs on the $\mathrm{BiOCl}$ microsphere surface. The surface area of $\mathrm{BiOCl}, \mathrm{Cu}_{2} \mathrm{ZnSnS}_{4}$ and BiOCl- $\mathrm{Cu}_{2} \mathrm{ZnSnS}_{4}-1$ was of $1.91 \mathrm{~m}^{2} / \mathrm{g}, 3.06 \mathrm{~m}^{2} / \mathrm{g}$ and $13.39 \mathrm{~m}^{2} / \mathrm{g}$, respectively. BiOCl- $\mathrm{Cu}_{2} \mathrm{ZnSnS}_{4}-1$ had a higher photodegradation rate for Congo red dye than $\mathrm{BiOCl}$ and $\mathrm{Cu}_{2} \mathrm{ZnSnS}_{4}$ QDs under sunlight, and that higher photoactivity was due to the heterostructure effect between $\mathrm{BiOCl}$ and $\mathrm{Cu}_{2} \mathrm{ZnSnS}_{4}$ QDs along with increased optical absorption in the visible region. Scavenger study endorses the involvement of superoxide and holes radicals in the degradation of Congo red.
\end{abstract}

Keywords $\mathrm{BiOCl}-\mathrm{Cu}_{2} \mathrm{ZnSnS}_{4} \cdot$ Heterostructure $\cdot$ Nanocomposite $\cdot$ Photodegradation $\cdot$ Congo red $\cdot$ Scavengers

\section{Introduction}

Semiconductor photocatalysis is a useful, low-cost and environmentally benign technique for solving environmental pollution problems. The scientific community is focused on a very challenging and relevant research's direction, for the synthesis of a better photocatalyst for hydrogen production, environmental pollution and many more. Bismuth oxychloride $(\mathrm{BiOCl})$ is one of the good adsorbents and photocatalyst for the elimination of organic pollutants such as dyes, phenols, bacteria as it possesses a high chemical stability ( $\mathrm{Li}$ et al. 2017). The good photocatalytic activity is attributed to layered structure consisting of alternate arrangement of $\left[\mathrm{Bi}_{2} \mathrm{O}_{2}\right]^{2+}$ monolayer and dual $\mathrm{Cl}$ layers (Ao et al. 2016). $\mathrm{BiOCl}$ had better photodegradation performance than commercial $\mathrm{TiO}_{2}$ (P25) under UV light irradiation. However, due to its large band gap (3.17-3.54 eV) decreases BiOCl photoactivity (Liu et al. 2016). Thus, it is necessary to overcome these limitations and it can be performed by forming

Baban H. Shambharkar

baban.shambharkar@gmail.com

1 Chemistry Department, National Institute of Technology Silchar, Assam 788 010, India heterostructured composites through coupling of $\mathrm{BiOCl}$ with another semiconductor having narrow band gap. The designed $\mathrm{BiOCl}$ heterostructured composite will possess better visible light response and also facilitate the separation of photoinduced electron-hole pairs due to synergistic effect which eventually provides excellent photodegradation of contaminants.

Copper zinc tin sulfide $\left(\mathrm{Cu}_{2} \mathrm{ZnSnS}_{4}\right)$ is a quaternary semiconducting compound of stannite structure. $\mathrm{Cu}_{2} \mathrm{ZnSnS}_{4}$ is an abundant, non-toxic component in the earth crust. The absorption coefficient of $\mathrm{Cu}_{2} \mathrm{ZnSnS}_{4}$ is $10^{4} \mathrm{~cm}^{-1}$. Its band gap is about 1.4-1.7 eV (Malerba et al. 2014). $\mathrm{Cu}_{2} \mathrm{ZnSnS}_{4}$ has shown to be an excellent light energy-harvesting material for solar cells and good chemical stability in the photodegradation of organics (Arbouz et al. 2017; Hou et al. 2014; Barpuzary et al. 2015).

BiOCl-based constructed heterostructures revealed the enhanced photocatalytic activity, for example, BiOCl- $\mathrm{La}_{2} \mathrm{Ti}_{2} \mathrm{O}_{7}$ (Ao et al. 2016), $\mathrm{Bi}_{2} \mathrm{~S}_{3}-\mathrm{BiOCl}$ (Xu et al. 2017), CdS-BiOCl (Pan et al. 2018), BiOCl- $\mathrm{ZnFe}_{2} \mathrm{O}_{4}$ (Sun et al. 2018), $\mathrm{AgCl}-\mathrm{BiOCl}$ (Cheng et al. 2014), $\mathrm{BiVO}_{4}-\mathrm{BiOCl}$ (He et al. 2014), $\mathrm{Co}_{3} \mathrm{O}_{4}-\mathrm{BiOCl}$ (Tana et al. 2014), $\mathrm{BiOCl}-\mathrm{TiO}_{2}$ (Li et al. 2016), $\mathrm{Bi}_{3} \mathrm{O}_{4} \mathrm{Br} / \mathrm{BiOCl}$ (Gao et al. 2010), $\mathrm{BiOCl} / \mathrm{C}_{3} \mathrm{~N}_{4}$ (Huang et al. 2017), $\alpha-\mathrm{Fe}_{2} \mathrm{O}_{3} /$ 
$\mathrm{BiOCl}$ (Zheng et al. 2018), $\mathrm{BiOCl}-\mathrm{Ag}_{3} \mathrm{PO}_{4}$ (Cao et al. 2013), BiOCl- $\mathrm{Ag}_{2} \mathrm{CO}_{3}$ (Fang et al. 2016), Ag-modified $\mathrm{BiOCl}$ (Yu et al. 2017), BiOCl- $\mathrm{SnO}_{2}$ (Sun et al. 2015), $\mathrm{Bi}_{2} \mathrm{MoO}_{6}-\mathrm{BiOCl}$ (Zuo et al. 2015), $\mathrm{CdS} / \mathrm{BiOCl}$ (Lin et al. 2017), BiOCl- $-\mathrm{Ag}_{8} \mathrm{SnS}_{6}$ (Shambharkar and Chowdhury 2018). This inspires us to fabricate a novel $\mathrm{BiOCl}-\mathrm{Cu}_{2} \mathrm{Zn}$ $\mathrm{SnS}_{4}$ heterostructure with the hope of boosting visible light absorption capacity for better photocatalytic activity than their single component.

In the present study, chemical coprecipitation method was employed for synthesizing $\mathrm{Cu}_{2} \mathrm{ZnSnS}_{4} \mathrm{QDs}(5-7 \mathrm{~nm})$. The prepared $\mathrm{Cu}_{2} \mathrm{ZnSnS}_{4}$ QDs were used for constructing $\mathrm{BiOCl}-\mathrm{Cu}_{2} \mathrm{ZnSnS}_{4}$ heterostructure through deposition of $\mathrm{Cu}_{2} \mathrm{ZnSnS}_{4}$ particles on the surface of $\mathrm{BiOCl}$ with the help of coprecipitation method. $\mathrm{BiOCl}-\mathrm{Cu}_{2} \mathrm{ZnSnS}_{4}$ heterostructure can extend the response of visible light and separate the photogenerated excitons very effectively and also increases the amount of reactive oxidative species under sunlight. As result, $\mathrm{BiOCl}-\mathrm{Cu}_{2} \mathrm{ZnSnS}_{4}$ heterostructure had a better photocatalytic performance than bare $\mathrm{BiOCl}$ and $\mathrm{Cu}_{2} \mathrm{ZnSnS}_{4}$ QDs. Till date, no study has been conducted on the synthesis of $\mathrm{BiOCl}-\mathrm{Cu}_{2} \mathrm{ZnSnS}_{4}$ heterostructured nanocomposites and evaluated its photocatalytic performance in the degradation of Congo red.

\section{Experimental procedure}

\section{Materials}

$\mathrm{Cu}\left(\mathrm{NO}_{3}\right)_{2} \cdot 3 \mathrm{H}_{2} \mathrm{O}$, ethylene glycol, $\mathrm{Bi}\left(\mathrm{NO}_{3}\right)_{3} \cdot 5 \mathrm{H}_{2} \mathrm{O}$ were procured from Fisher Scientific Ltd. $\mathrm{ZnCl}_{2}, \mathrm{SnCl}_{2} \cdot 2 \mathrm{H}_{2} \mathrm{O}$, thiourea, potassium chloride were purchased from Merck. Congo red dye was procured from SRL. Distilled water was used to carry out the experiments.

\section{Production of $\mathrm{Cu}_{2} \mathrm{ZnSnS}_{4}$ QDs, BiOCl and BiOCl- $\mathrm{Cu}_{2} \mathrm{ZnSnS}_{4}$ heterostructures}

$\mathrm{Cu}_{2} \mathrm{ZnSnS}_{4}$ QDs were prepared by chemical coprecipitation (Shambharkar and Chowdhury 2018; Shambharkar and Chowdhury 2016). $0.1 \mathrm{M} \mathrm{Cu}\left(\mathrm{NO}_{3}\right)_{3},(0.05 \mathrm{M}) \mathrm{ZnCl}_{2}$, $(0.05 \mathrm{M}) \mathrm{SnCl}_{2}$ solutions were taken in a round-bottomed flask, and $50 \mathrm{ml}$ of ethylene glycol (EG) and $10 \mathrm{~g}$ of thiourea were added into it and then heated it at $160{ }^{\circ} \mathrm{C}, 6 \mathrm{~h}$. The black precipitate of $\mathrm{Cu}_{2} \mathrm{ZnSnS}_{4}$ QDs was acquired and washed with methanol to remove EG and dried.

At the initial stage of reaction, $\mathrm{Sn}^{2+}, \mathrm{Cu}^{+}, \mathrm{Zn}^{2+}$ ions combine with EG to form Sn-EG, Cu-EG, Zn-EG. When thiourea was added into the reaction system, $\mathrm{Sn}^{2+}, \mathrm{Cu}^{+}$ and $\mathrm{Zn}^{2+}$ ions form complex with thiourea and yielded $\mathrm{Sn}$-thiourea, $\mathrm{Cu}$-thiourea and $\mathrm{Zn}$-thiourea complexes. These complexes undergo thermal decomposition at $160{ }^{\circ} \mathrm{C}$ to produce EG-capped $\mathrm{Cu}_{2} \mathrm{ZnSnS}_{4}$ QDs. The possible reactions occurred during the preparation of $\mathrm{Cu}_{2} \mathrm{ZnSnS}_{4}$ QDs were as follows:

$$
\begin{aligned}
2 \mathrm{Cu}^{+}+n(\mathrm{EG}) & \rightarrow\left[2 \mathrm{Cu}(\mathrm{EG})_{n}\right]^{+} \\
\mathrm{Zn}^{2+}+n(\mathrm{EG}) & \rightarrow\left[\mathrm{Zn}(\mathrm{EG})_{n}\right]^{2+} \\
\mathrm{Sn}^{2+}+n(\mathrm{EG}) & \rightarrow\left[\mathrm{Sn}(\mathrm{EG})_{n}\right]^{2+} \\
2 \mathrm{Cu}^{+}+n\left(\mathrm{SCH}_{2} \mathrm{H}_{4}\right) & \rightarrow\left[2 \mathrm{Cu}\left(\mathrm{SCN}_{2} \mathrm{H}_{4}\right)_{n}\right]^{2+} \\
\mathrm{Zn}^{2+}+n\left(\mathrm{SCN}_{2} \mathrm{H}_{4}\right) & \rightarrow\left[\mathrm{Zn}\left(\mathrm{SCH}_{2} \mathrm{H}_{4}\right)_{n}\right]^{2+} \\
\mathrm{Sn}^{2+}+n\left(\mathrm{SCH}_{2} \mathrm{H}_{4}\right) & \rightarrow\left[\mathrm{Sn}\left(\mathrm{SCN}_{2} \mathrm{H}_{4}\right)_{n}\right]^{2+} \\
{\left[2 \mathrm{Cu}\left(\mathrm{SCN}_{2} \mathrm{H}_{4}\right)_{n}\right]^{2+} } & +\left[\mathrm{Zn}\left(\mathrm{SCN}_{2} \mathrm{H}_{4}\right)_{n}\right]^{2+} \\
{\left[\mathrm{Sn}\left(\mathrm{SCN}_{2} \mathrm{H}_{4}\right)_{n}\right]^{2+} } & \stackrel{160^{\circ} \mathrm{C}, 6 \mathrm{~h}}{\longrightarrow} \mathrm{Cu}_{2} \mathrm{ZnSnS}_{4}
\end{aligned}
$$

BiOCl- $\mathrm{Cu}_{2} \mathrm{ZnSnS}_{4}-1$ heterostructured nanocomposite was obtained from coprecipitation method. $100 \mathrm{mg}$ of $\mathrm{Cu}_{2} \mathrm{ZnSnS}_{4}$ QDs was mixed with bismuth nitrate solution $(0.01 \mathrm{M}), 20 \mathrm{ml}$ of $\mathrm{EG}$, and $1 \mathrm{~g}$ of $\mathrm{KCl}$. The reaction mixture was stirred and heated at $100{ }^{\circ} \mathrm{C}, 4 \mathrm{~h}$. Gray color precipitate of $\mathrm{BiOCl}-\mathrm{Cu}_{2} \mathrm{ZnSnS}_{4}$ was formed. Subsequently, the final product was washed to remove EG with methanol and dried at $80^{\circ} \mathrm{C}$. Similar procedure was followed for preparing $\mathrm{BiOCl}-\mathrm{Cu}_{2} \mathrm{ZnSnS}_{4}-2$ using $150 \mathrm{mg}$ of $\mathrm{Cu}_{2} \mathrm{ZnSnS}_{4}$ QDs. BiOCl microspheres were obtained from our published procedure (Shambharkar and Chowdhury 2018).

\section{Characterization techniques}

Crystallinity and purity of $\mathrm{Cu}_{2} \mathrm{ZnSnS}_{4}$ QDs, BiOCl and $\mathrm{BiOCl}-\mathrm{Cu}_{2} \mathrm{ZnSnS}_{4}$ were determined by conducting X-ray diffraction (XRD) on Bruker AXS D8 ADVANCE X-ray diffractometer. Transmission electron microscope was performed on JEOL Model JEM-2100 to assess the morphology of samples. Band gap energy was obtained from UV-visible diffuse reflectance spectra (Varian, Cary 5000 UV-Vis NIR spectrophotometer). Surface area of the samples was determined from $\mathrm{N}_{2}$ adsorption-desorption isotherms (Micromeritics ASAP 2020), and photoluminescence (PL) spectra were recorded by JY Fluorolog-3-11 fluorescence spectrofluorimeter with Xenon Lamp ( $450 \mathrm{~W}$ ) as excitation source with excitation wavelength $310 \mathrm{~nm}$.

Photocatalytic activity of $\mathrm{BiOCl}, \mathrm{Cu}_{2} \mathrm{ZnSnS}_{4}$ QDs and $\mathrm{BiOCl}-\mathrm{Cu}_{2} \mathrm{ZnSnS}_{4}$ was evaluated by conducting degradation studies using Congo red dye $(20 \mathrm{mg} / \mathrm{l})$ under direct sunlight irradiation. $\mathrm{BiOCl}-\mathrm{Cu}_{2} \mathrm{ZnSnS}_{4}$ powder $(100 \mathrm{mg})$ was added in $80 \mathrm{ml}$ of Congo red solution and agitated in the dark to ensure adsorption-desorption equilibrium before light irradiation. A solution of $5 \mathrm{ml}$ from the mixture was taken out after irradiation time was over and centrifuged. 
Absorbance the dye was measured at $\lambda_{\max }=497 \mathrm{~nm}$ on Cary 100 Bio UV-Vis spectrophotometer. The similar technique was accepted for $\mathrm{BiOCl}$ and $\mathrm{Cu}_{2} \mathrm{ZnSnS}_{4}$ nanoparticles, and the photodegradation performance of samples was studied.

\section{Results and discussion}

\section{XRD, TEM, UV-visible NIR, PL and BET studies}

XRD pattern of $\mathrm{BiOCl}, \mathrm{Cu}_{2} \mathrm{ZnSnS}_{4}$ QDs and $\mathrm{BiOCl}-\mathrm{Cu}_{2} \mathrm{Z}-$ $\mathrm{nSnS}_{4}$ is shown in Fig. 1a-c. The diffracted peaks of the synthesized $\mathrm{Cu}_{2} \mathrm{ZnSnS}_{4}$ QDs were matched with JCPDS file 00-026-0575 (Kesterite, syn) with crystal system tetragonal. The crystallite size of $\mathrm{Cu}_{2} \mathrm{ZnSnS}_{4} \mathrm{QDs}$ was obtained from Debye Scherrer formula, $D=0.99 \lambda / \beta \cos \theta$, where $\beta$ is full width at half maximum of the diffracted peak, $\lambda$ is the $\mathrm{X}$-ray wavelength and $\theta$ is the angle of diffraction and it was found to be $7 \mathrm{~nm}$. BiOCl- $\mathrm{Cu}_{2} \mathrm{ZnSnS}_{4}$ heterostructure displayed the typical BiOCl signals (JCPDS file 01-085-0861). Characteristic peaks of $\mathrm{Cu}_{2} \mathrm{ZnSnS}_{4}$ QDs were not seen in the pattern of $\mathrm{BiOCl}-\mathrm{Cu}_{2} \mathrm{ZnSnS}_{4}$ which may be due to low content of $\mathrm{Cu}_{2} \mathrm{ZnSnS}_{4}$ QDs in the composite (Fig. 1c). The surface morphology and the interaction of $\mathrm{Cu}_{2} \mathrm{ZnSnS}_{4}$ QDs with $\mathrm{BiOCl}$ were studied from TEM (Fig. 2a-f). From Fig. 2e-f, it was seen that $\mathrm{Cu}_{2} \mathrm{ZnSnS}_{4}$ nanoparticles $(5-7 \mathrm{~nm})$ were deposited on $\mathrm{BiOCl}$ microsphere surface to form interface linking between $\mathrm{BiOCl}$ and $\mathrm{Cu}_{2} \mathrm{ZnSnS}_{4}$ QDs. The EDX data (Fig. 3) of BiOCl- $\mathrm{Cu}_{2} \mathrm{ZnSnS}_{4}$ revealed the presence of elements $\mathrm{O}, \mathrm{S}, \mathrm{Cl}, \mathrm{Cu}, \mathrm{Zn}, \mathrm{Sn}$ and $\mathrm{Bi}$ and were distributed homogenously in the composite.

UV-Vis NIR absorption spectra of BiOCl, $\mathrm{Cu}_{2} \mathrm{ZnSnS}_{4} \mathrm{QDs}$ and $\mathrm{BiOCl}-\mathrm{Cu}_{2} \mathrm{ZnSnS}_{4}$ are shown in Fig. 4. $\mathrm{Cu}_{2} \mathrm{ZnSnS}_{4}$ QDs absorbed UV-visible light up to near infrared region, while UV radiation was absorbed by $\mathrm{BiOCl}$ and $\mathrm{BiOCl}-\mathrm{Cu}_{2} \mathrm{ZnSnS}_{4}$ composites exhibited a mixed absorption (Fig. 4b). The band gap energy (Eg) for $\mathrm{BiOCl}$ microspheres, $\mathrm{Cu}_{2} \mathrm{ZnSnS}_{4}$ QDs and BiOCl- $\mathrm{Cu}_{2} \mathrm{ZnSnS}_{4}$ was obtained from Tauc equation (Xiao et al. 2018), and the plots are shown in Fig. 5a-d. The obtained $\mathrm{Eg}$ value of $\mathrm{BiOCl}$ microspheres was closed to $3.46 \mathrm{eV}$ (Zang et al. 2006). The Eg value was decreased on loading of $\mathrm{Cu}_{2} \mathrm{ZnSnS}_{4}$ QDs in composites (Table 1) which may be aroused from synergistic effect between $\mathrm{Cu}_{2} \mathrm{ZnSnS}_{4}$ QDs and $\mathrm{BiOCl}$ in lowering the band gap.

To study the charge recombination over $\mathrm{BiOCl}-\mathrm{Cu}_{2} \mathrm{Z}$ $\mathrm{nSnS}_{4}$ heterostructures, PL responses were taken and the plots were presented in Fig. 6. At excitation wavelength of $310 \mathrm{~nm}, \mathrm{BiOCl}$ shows PL intensity with emission peaks at $313 \mathrm{~nm}, 360 \mathrm{~nm}$ and $625 \mathrm{~nm}$. The emission intensity was decreased on incorporating $\mathrm{Cu}_{2} \mathrm{ZnSnS}_{4}$ QDs in the $\mathrm{BiOCl}-\mathrm{Cu}_{2} \mathrm{ZnSnS}_{4}-1$. This was occurred due to
Fig. 1 XRD pattern of $\mathbf{a}$ $\mathrm{Cu}_{2} \mathrm{ZnSnS}_{4}$ QDs, b $\mathrm{BiOCl}$ and $\mathbf{c}$ $\mathrm{BiOCl}-\mathrm{Cu}_{2} \mathrm{ZnSnS}_{4}-1$
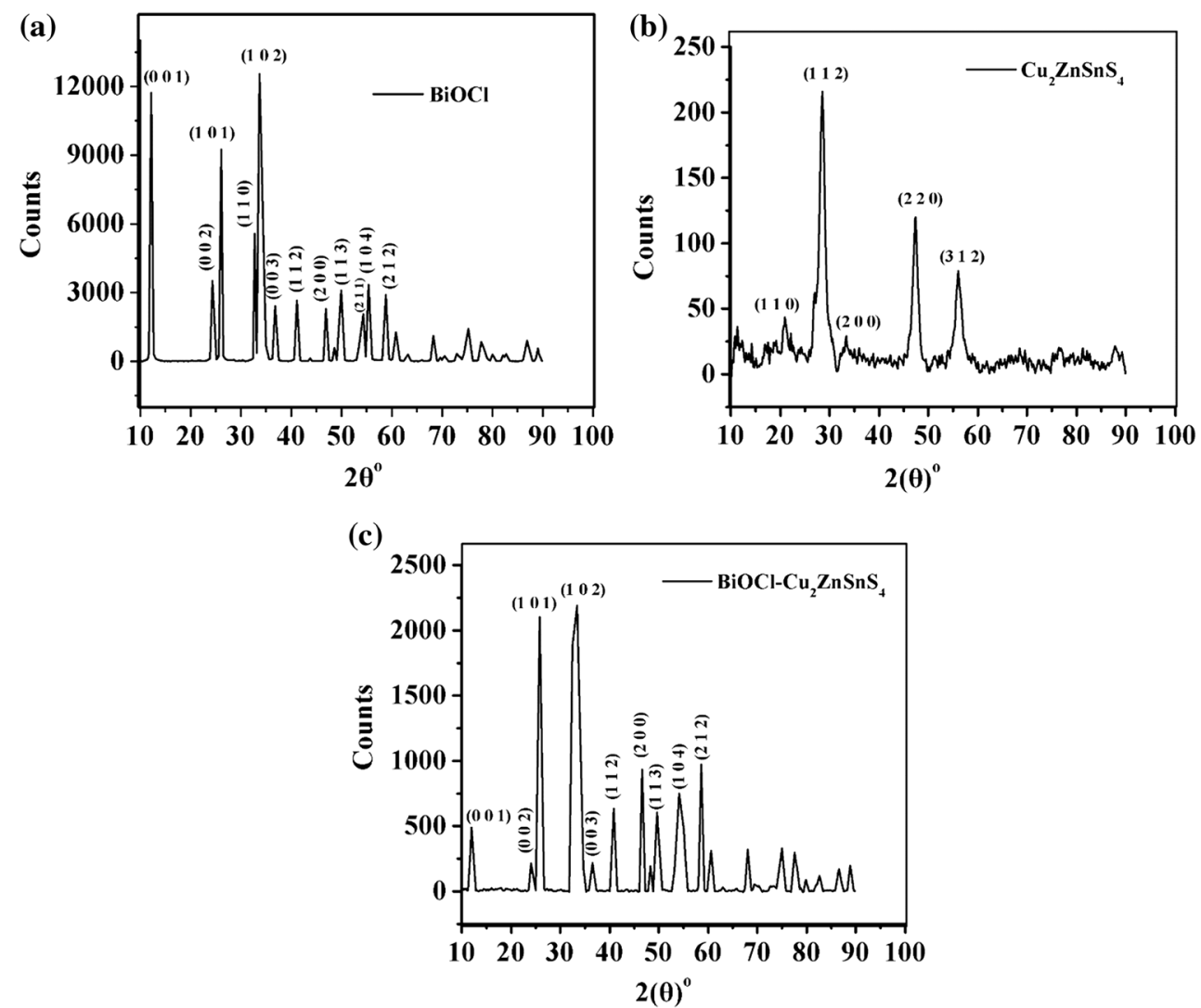

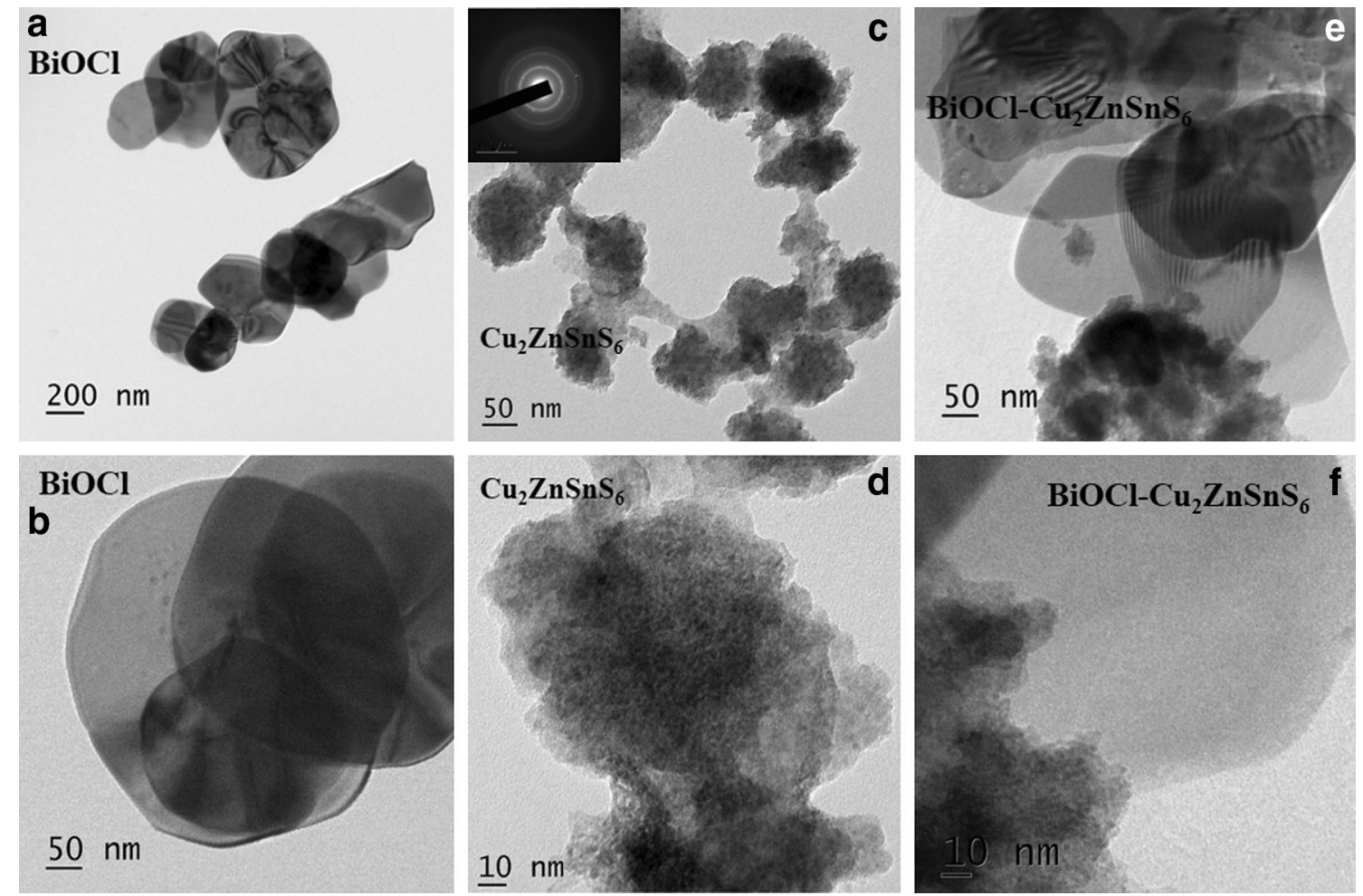

Fig. 2 TEM images of $\mathrm{BiOCl}(\mathbf{a}, \mathbf{b}), \mathrm{Cu}_{2} \mathrm{ZnSnS}_{4}$ QDs $(\mathbf{c}, \mathbf{d})$ and $\mathrm{BiOCl}-\mathrm{Cu}_{2} \mathrm{ZnSnS}_{4}-1(\mathbf{e}, \mathbf{f})$

Fig. 3 EDX spectra of $\mathrm{BiOCl}$ $\mathrm{Cu}_{2} \mathrm{ZnSnS}_{4}-1$

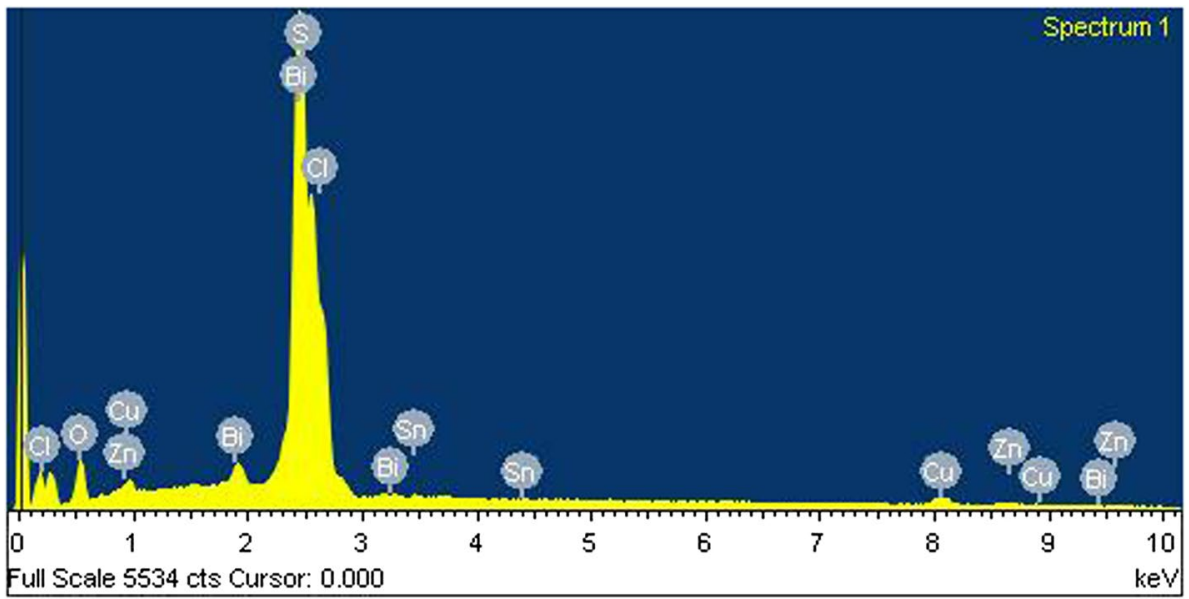

$\mathrm{N}_{2}$ adsorption-desorption isotherms of $\mathrm{Cu}_{2} \mathrm{ZnSnS}_{4}$

the isolation of electrons and holes by coupling $\mathrm{BiOCl}$ with $\mathrm{Cu}_{2} \mathrm{ZnSnS}_{4}$. On further addition of $\mathrm{Cu}_{2} \mathrm{ZnSnS}_{4}$ in $\mathrm{BiOCl}-\mathrm{Cu}_{2} \mathrm{ZnSnS}_{4}-2$, the PL intensity was increased because of the recombination of isolated electrons and holes. Thus, our findings have shown that $\mathrm{BiOCl}-\mathrm{Cu}_{2} \mathrm{Z}-$ $\mathrm{nSnS}_{4^{-}} 1$ heterostructure exhibited the best $e^{-}-h^{+}$pair separation. QDs, $\mathrm{BiOCl}$ and $\mathrm{BiOCl}-\mathrm{Cu}_{2} \mathrm{ZnSnS}_{4}$ were of type III (Fig. 7), and the surface area of $\mathrm{BiOCl}-\mathrm{Cu}_{2} \mathrm{ZnSnS}_{4}$ was increased after adding $\mathrm{Cu}_{2} \mathrm{ZnSnS}_{4}$ QDs in composite (Table 1). The pore volume of $\mathrm{BiOCl}-\mathrm{Cu}_{2} \mathrm{ZnSnS}_{4}$ was of $0.076 \mathrm{~cm}^{3} / \mathrm{g}$. 
Fig. 4 UV-visible light-NIR absorption spectrum of $\mathrm{BiOCl}$ microspheres, $\mathrm{BiOCl}-\mathrm{Cu}_{2} \mathrm{Zn}$ $\mathrm{SnS}_{4}-1, \mathrm{BiOCl}-\mathrm{Cu}_{2} \mathrm{ZnSnS}_{4}-2$ and $\mathrm{Cu}_{2} \mathrm{ZnSnS}_{4}$

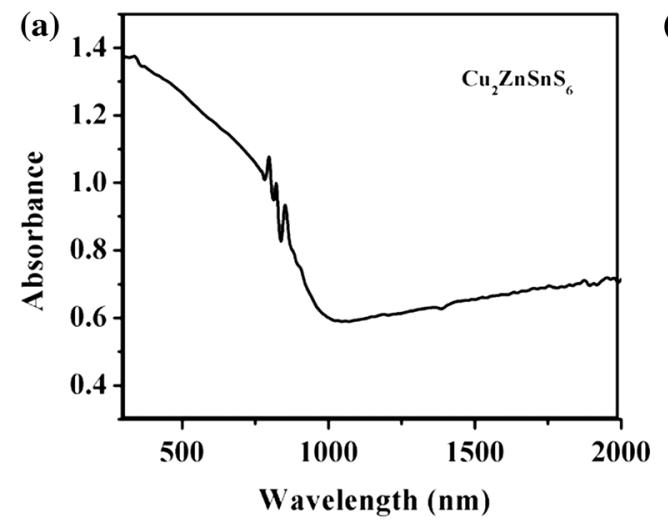

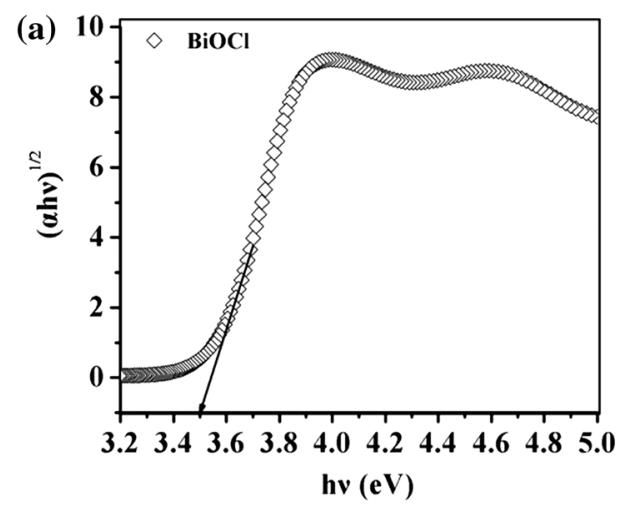

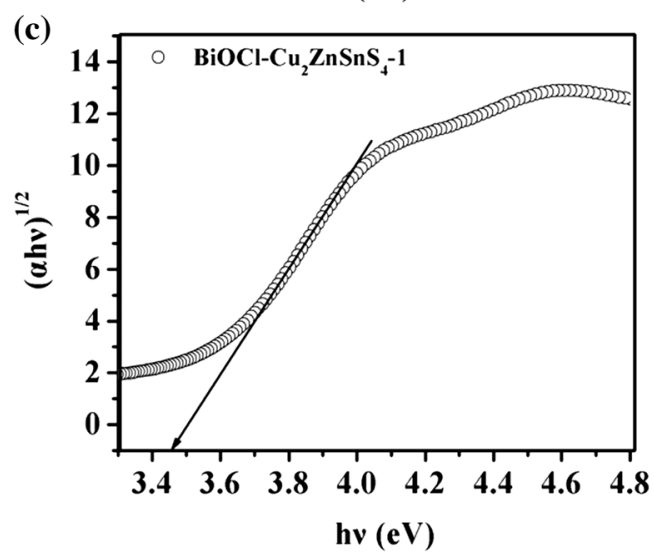

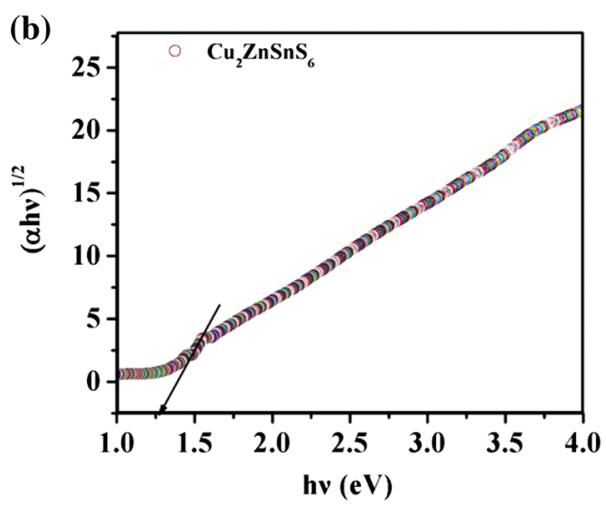

(d)

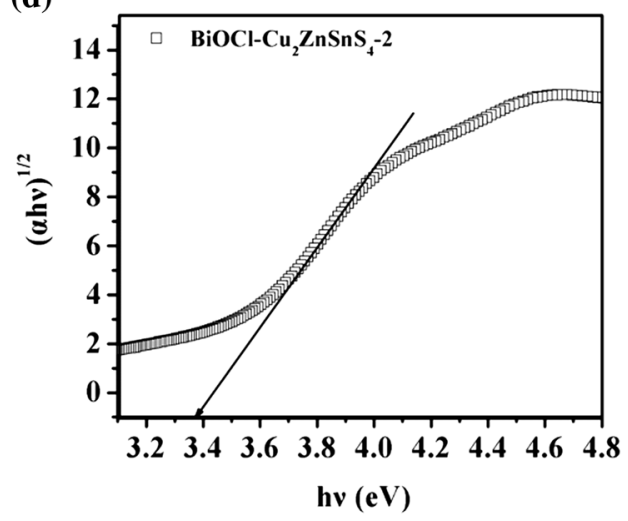

Fig. 5 Tauc plots of $(\alpha h v)^{1 / 2}$ versus photon energy $(h v)$ of a $\mathrm{BiOCl}$ microspheres, $\mathbf{b} \mathrm{Cu}_{2} \mathrm{ZnSnS}_{4}$ QDs, $\mathbf{c} \mathrm{BiOCl}_{-} \mathrm{Cu}_{2} \mathrm{ZnSnS}_{4}-1$ and $\mathbf{d}$ BiOCl$\mathrm{Cu}_{2} \mathrm{ZnSnS}_{4}-2$

Table 1 Rate constant, band gap energy and surface area of prepared $\mathrm{BiOCl}$ microspheres, $\mathrm{Cu}_{2} \mathrm{ZnSnS}_{4}$ QDs and BiOCl$\mathrm{Cu}_{2} \mathrm{ZnSnS}_{4}$

\begin{tabular}{llllll}
\hline Samples & $\begin{array}{l}\text { Indirect band } \\
\text { gap }(\mathrm{eV})\end{array}$ & $E_{\mathrm{VB}}(\mathrm{eV})$ & $E_{\mathrm{CB}}(\mathrm{eV})$ & $\begin{array}{l}\text { Surface area } \\
\left(\mathrm{m}^{2} / \mathrm{g}\right)\end{array}$ & Rate $(k)\left(\mathrm{min}^{-1}\right)$ \\
\hline $\mathrm{Cu}_{2} \mathrm{ZnSnS}{ }_{4} \mathrm{QDs}$ & 1.29 & 1.435 & 0.145 & 3.06 & 0.011 \\
$\mathrm{BiOCl}$ & 3.49 & 3.60 & 0.11 & 1.91 & 0.0019 \\
$\mathrm{BiOCl}-\mathrm{Cu}_{2} \mathrm{ZnSnS}_{4}-1$ & 3.45 & & & 13.39 & 0.0265 \\
$\mathrm{BiOCl}-\mathrm{Cu}_{2} \mathrm{ZnSnS}_{4}-2$ & 3.37 & & - & 0.0012 \\
\hline
\end{tabular}

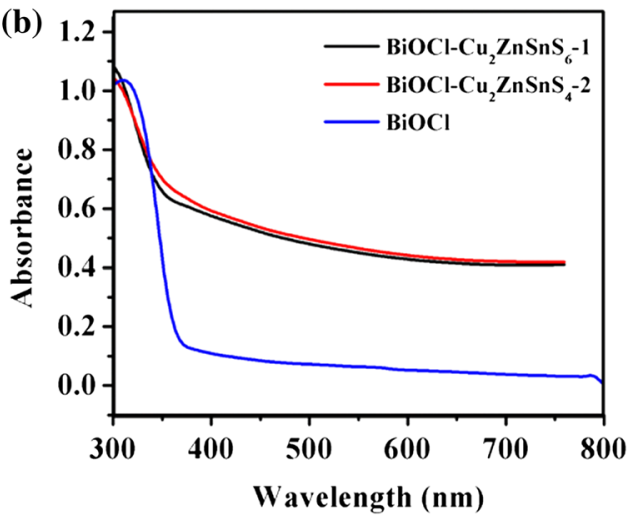




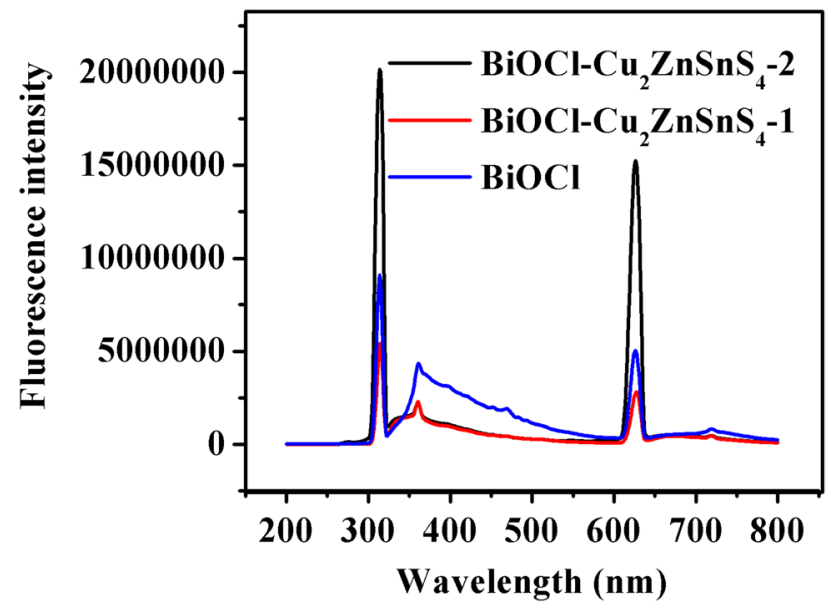

Fig. 6 Photoluminescence spectra of $\mathrm{BiOCl}, \mathrm{BiOCl}-\mathrm{Cu}_{2} \mathrm{ZnSnS}_{4}-1$ and $\mathrm{BiOCl}-\mathrm{Cu}_{2} \mathrm{ZnSnS}_{4}-2$

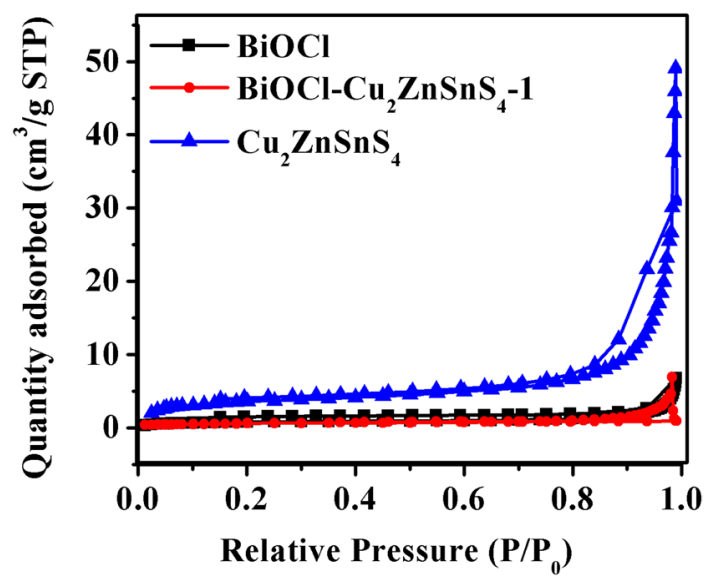

Fig. $7 \mathrm{~N}_{2}$ adsorption-desorption isotherms of as-prepared $\mathrm{BiOCl}$ microspheres, $\mathrm{Cu}_{2} \mathrm{ZnSnS}_{4}$ QDs and $\mathrm{BiOCl}-\mathrm{Cu}_{2} \mathrm{ZnSnS}_{4}-1$

\section{Photocatalytic performance}

After sunlight irradiation, absorbance spectra of Congo red dye solution in the presence of $\mathrm{BiOCl}$ microspheres, $\mathrm{Cu}_{2} \mathrm{ZnSnS}_{4}$ QDs and $\mathrm{BiOCl}-\mathrm{Cu}_{2} \mathrm{ZnSnS}_{4}$ were measured (Fig. 8a-d). The Congo red molecules were degraded completely in the presence of $\mathrm{BiOCl}-\mathrm{Cu}_{2} \mathrm{ZnSnS}_{4}-1$ photocatalyst, and the degradation efficiency was represented in Fig. 9a. BiOCl- $\mathrm{Cu}_{2} \mathrm{ZnSnS}_{4}-1$ showed higher photodegradation and degraded $94.9 \%$ of Congo red dye after $90 \mathrm{~min}$ of sunlight irradiation. The photodegradation rate constant of Congo red was higher for heterostructure than for bare $\mathrm{BiOCl}$ and $\mathrm{Cu}_{2} \mathrm{ZnSnS}_{4}$ QDs (Fig. 9c). The improved photocatalytic activity of $\mathrm{BiOCl}-\mathrm{Cu}_{2} \mathrm{ZnSnS}_{4}$ was endorsed to the formation of heterostructure between $\mathrm{BiOCl}$ and $\mathrm{Cu}_{2} \mathrm{ZnSnS}_{4}$ QDs that improved separation and transport of photogenerated charge carriers. The degradation behavior of $\mathrm{BiOCl}-\mathrm{Cu}_{2} \mathrm{ZnSnS}_{4}$ was compared with commercial P25 $\mathrm{TiO}_{2}$ and it was observed that the degradation efficiency of $\mathrm{BiOCl}-\mathrm{Cu}_{2} \mathrm{ZnSnS}_{4}$ was lesser than that of $\mathrm{P} 25 \mathrm{TiO}_{2}$ towards Congo red (Shambharkar and Chowdhury 2018).

The band edge positions of $\mathrm{BiOCl}$ and $\mathrm{Cu}_{2} \mathrm{ZnSnS}_{4}$ (Zheng et al. 2018; Cao et al. 2013) were determined (Table 1). The $\chi$ value for $\mathrm{Cu}_{2} \mathrm{ZnSnS}_{4}$ QDs was calculated to be 5.29, and $\chi$ value for $\mathrm{BiOCl}$ was calculated to be 6.36 (Sun et al. 2015). The $\mathrm{CB}$ of $\mathrm{Cu}_{2} \mathrm{ZnSnS}_{4}$ QDs was higher than $\mathrm{CB}$ of $\mathrm{BiOCl}$. Therefore, the photoinduced electrons from the conduction band of $\mathrm{Cu}_{2} \mathrm{ZnSnS}_{4}$ QDs were inserted to the conduction band of $\mathrm{BiOCl}$. Meanwhile, the photogenerated holes on the valence band of $\mathrm{BiOCl}$ were moved to valence band of $\mathrm{Cu}_{2} \mathrm{ZnSnS}_{4}$. This process resulted in heterojunction at the interface of the two compounds (Fig. 10). The holes react with $\mathrm{H}_{2} \mathrm{O}$ and generate $\mathrm{OH}$ radicals. The electrons combine with $\mathrm{O}_{2}$ to yield active superoxide radical anion of oxygen and decomposed the Congo red dye on the catalyst surface. The degradation experiment was repeated using the $\mathrm{BiOCl}-\mathrm{Cu}_{2} \mathrm{Zn}$ $\mathrm{SnS}_{4}$. BiOCl- $\mathrm{Cu}_{2} \mathrm{ZnSnS}_{4}$ heterostructure had retained its stability up to four cycles.

Various scavengers like isopropanol (Pr) for ${ }^{\bullet} \mathrm{OH}$ radicals, ammonium oxalate (AO) for $h^{+}, 1,4$-benzoquinone (BQ) for $\mathrm{O}_{2}^{-}$radicals were mixed with Congo red solution containing BiOCl- $\mathrm{Cu}_{2} \mathrm{ZnSnS}_{4}$ compound, and the photocatalytic activity was executed. From Fig. 9b, it was observed that $\mathrm{AO}$ and $\mathrm{BQ}$ were inhibited the photodegradation reaction. Therefore, the possible reactions happened over $\mathrm{BiOCl}-\mathrm{Cu}_{2} \mathrm{ZnSnS}_{4}$ heterostructure in the degradation of the dye were given below.

$$
\begin{aligned}
\mathrm{BiOCl}-\mathrm{Cu}_{2} \mathrm{ZnSnS}_{4}+h v & \rightarrow \mathrm{BiOCl}-\mathrm{Cu}_{2} \mathrm{ZnSnS}_{4}\left(h_{\mathrm{VB}}^{+}+e_{\mathrm{CB}}^{-}\right) \\
\left(h_{\mathrm{VB}}^{+}+e_{\mathrm{CB}}^{-}\right) & \rightarrow \text { Energy } \\
e_{\mathrm{CB}}^{-}+\mathrm{O}_{2} & \rightarrow \mathrm{O}_{2}^{--} \\
h_{\mathrm{VB}}^{+}+2 \mathrm{H}_{2} \mathrm{O} & \rightarrow \mathrm{OH}+\mathrm{H}_{3} \mathrm{O}^{+} \\
\mathrm{O}_{2}^{--}+\mathrm{H}^{+} & \rightarrow \mathrm{OOH} \\
\mathrm{OOH}+\mathrm{OOH} & \rightarrow \mathrm{H}_{2} \mathrm{O}_{2}+\mathrm{O}_{2} \\
\mathrm{O}_{2}^{-}+\text {Congo red } & \rightarrow \text { Intermediates } \rightarrow \mathrm{CO}_{2}+\mathrm{H}_{2} \mathrm{O} \\
\mathrm{OOH}+\text { Congo red } & \rightarrow \text { Degradation products } \\
\mathrm{OH}+\text { Congo red } & \rightarrow \text { Degradation products }
\end{aligned}
$$

\section{Conclusions}

Facile coprecipitation method was employed for constructing a new $\mathrm{BiOCl}-\mathrm{Cu}_{2} \mathrm{ZnSnS}_{4}$ heterostructure. $\mathrm{BiOCl}-\mathrm{Cu}_{2} \mathrm{ZnSnS}_{4}-1$ heterostructured composite showed superior photocatalytic activity in the degradation of Congo red than single phase $\mathrm{BiOCl}$ and $\mathrm{Cu}_{2} \mathrm{ZnSnS}_{4}$ QDs 
Fig. 8 UV-visible absorbance spectra of Congo red before and after solar light irradiation in the presence of a $\mathrm{BiOCl}$ microspheres, $\mathbf{b} \mathrm{Cu}_{2} \mathrm{ZnSnS}_{4}$ QDs, c BiOCl- $\mathrm{Cu}_{2} \mathrm{ZnSnS}_{4}-1$ and d $\mathrm{BiOCl}-\mathrm{Cu}_{2} \mathrm{ZnSnS}_{4}-2$
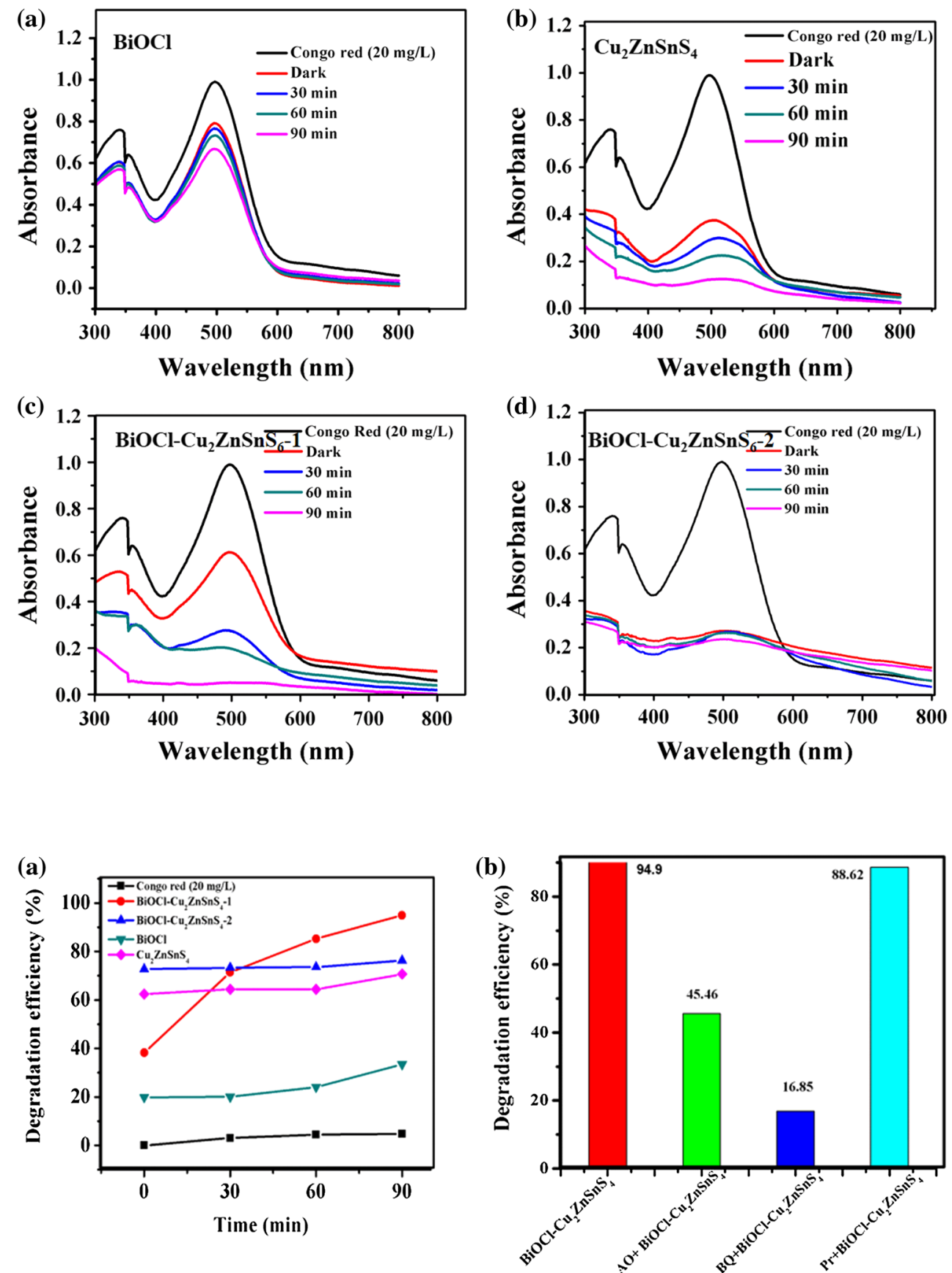

(c)

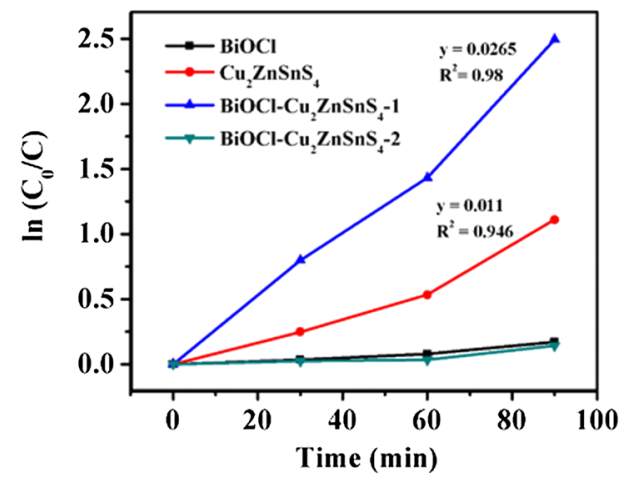

(d)

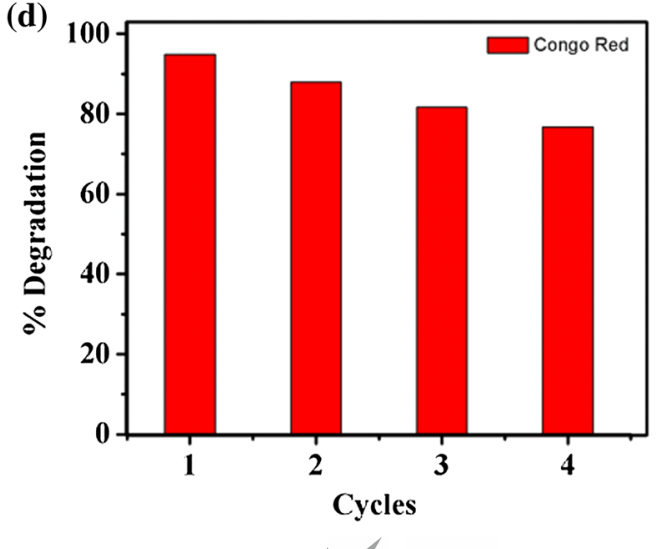




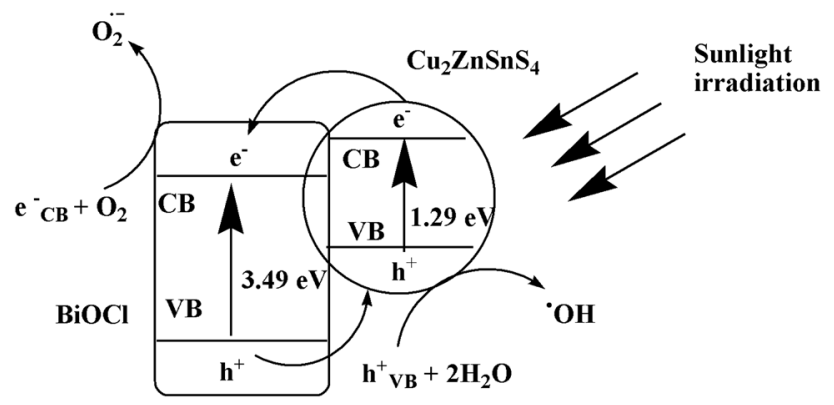

Fig. 10 Scheme of electron transfer in $\mathrm{BiOCl}-\mathrm{Cu}_{2} \mathrm{ZnSnS}_{4}$ heterostructure

in the presence of sunlight. The degradation of Congo red was achieved $94.9 \%$ in 90 min of sunlight irradiation. The photoactivity of $\mathrm{BiOCl}-\mathrm{Cu}_{2} \mathrm{ZnSnS}_{4}-1$ was due to the generation of heterostructure between $\mathrm{BiOCl}$ and $\mathrm{Cu}_{2} \mathrm{ZnSnS}_{4}$, which separates the photoexcited electron-hole pairs in the interface of $\mathrm{BiOCl}$ and $\mathrm{Cu}_{2} \mathrm{ZnSnS}_{4}$ on absorption of visible light radiation. The recombination of $e^{-}$and $h^{+}$in $\mathrm{BiOCl}$ was removed by constructing $\mathrm{BiOCl}-\mathrm{Cu}_{2} \mathrm{ZnSnS}_{4}$ heterostructure. The created $\mathrm{BiOCl}-\mathrm{Cu}_{2} \mathrm{ZnSnS}_{4}$ heterostructure can be used as a promising photocatalyst for environmental cleanup.

Open Access This article is distributed under the terms of the Creative Commons Attribution 4.0 International License (http://creativeco mmons.org/licenses/by/4.0/), which permits unrestricted use, distribution, and reproduction in any medium, provided you give appropriate credit to the original author(s) and the source, provide a link to the Creative Commons license, and indicate if changes were made.

\section{References}

Ao Y, Wang K, Wang P, Wang C, Hou J (2016) Fabrication of p-type $\mathrm{BiOCl} / \mathrm{n}$-type $\mathrm{La}_{2} \mathrm{Ti}_{2} \mathrm{O}_{7}$ facet coupling heterostructure with enhanced photocatalytic performance. RSC Adv 6:48599

Arbouz H, Aissat A, Vilco JP (2017) Simulation and optimization of CdS-n/ $/ \mathrm{Cu}_{2} \mathrm{ZnSnS}_{4}$ structure for solar cell applications. Int $\mathbf{J}$ Hydrog Energy 42:8827-8832

Barpuzary D, Banik A, Gogoi G, Qureshi M (2015) Noble metal-free counter electrode utilizing $\mathrm{Cu}_{2} \mathrm{ZnSnS}_{4}$ loaded with $\mathrm{MoS}_{2}$ for efficient solar cells based on $\mathrm{ZnO}$ nanowires cosensitized with $\mathrm{CuInS}_{2}-\mathrm{CdSe}$ quantum dots. Mater Chem A3:14378-14388

Cao B, Dong P, Cao S, Wang Y (2013) BiOCl/ $/ \mathrm{Ag}_{3} \mathrm{PO}_{4}$ composites with highly enhanced ultraviolet and visible light photocatalytic performances. J Am Ceram Soc 96:544-548

Cheng J, Wang C, Cui Y, Sun Y, Zuo Y, Wang T (2014) Large improvement of visible-light-driven photocatalytic property in $\mathrm{AgCl}$ nanoparticles modified black $\mathrm{BiOCl}$ microsphere. Mater Lett 127:28-31

Fang S, Ding C, Liang Q, Li Z, Xu S, Peng Y, Lu D (2016) In-situ precipitation synthesis of novel $\mathrm{BiOCl} / \mathrm{Ag}_{2} \mathrm{CO}_{3}$ hybrids with highly efficient visible-light-driven photocatalytic activity. J Alloys Compd 684:230-236
Gao B, Chakraborty AK, Yang JM, Lee W (2010) Visible-light photocatalytic activity of $\mathrm{BiOCl} / \mathrm{Bi}_{3} \mathrm{O}_{4} \mathrm{Cl}$ nanocomposites. Bull Korean Chem Soc 31:1941-1944

He Z, Shi Y, Gao C, Wen L, Chen J, Song S (2014) BiOCl/BiVO ${ }_{4} p-n$ heterojunction with enhanced photocatalytic activity under visible-light irradiation. J Phys Chem C 118:389-398

Hou X, Li Y, Yan J-J, Wang C-W (2014) Highly efficient photocatalysis of p-type $\mathrm{Cu}_{2} \mathrm{ZnSnS}_{4}$ under visible-light illumination. Mater Res Bull 60:628-633

Huang Y, Kang S, Gong W, Fang Y, Qin H, Liu S, Yang S, Li X (2017) $\mathrm{BiOCl}$ nanoplates decorated on $\mathrm{g}-\mathrm{C}_{3} \mathrm{~N}_{4}$ for enhanced photocatalytic activities. Int J Electrochem Sci 12:4351-4359

Li W, Tian Y, Li H, Zhao C, Zhang B, Zhang H, Geng W, Zhang $\mathrm{Q}$ (2016) Novel $\mathrm{BiOCl} / \mathrm{TiO}_{2}$ hierarchical composites: synthesis, characterization and application on photocatalysis. Appl Catal A 516:81-89

Li K, Liang Y, Yang J, Gao Q, Zhu Y, Liu S, Xu R, Wu X (2017) Controllable synthesis of 001 facet dependent four square $\mathrm{BiOCl}$ nanosheets: a high efficiency photocatalyst for degradation of methyl orange. J Alloys Compd 695:238-249

Lin W, Yu X, Shen Y, Chen H, Zhu Y, Zhang Y, Meng H (2017) Carbon dots/BiOCl films with enhanced visible light photocatalytic performance. J Nanopart Res 56:1-11

Liu X, Su Y, Zhao Q, Du C, Liu Z (2016) Constructing $\mathrm{Bi}_{24} \mathrm{O}_{31} \mathrm{Cl}_{10}$ / $\mathrm{BiOCl}$ heterojunction via a simple thermal annealing route for achieving enhanced photocatalytic activity and selectivity. Sci Rep, Sci. https://doi.org/10.1038/srep28689

Malerba C, Biccari F, Ricardo CLA, Valentini M, Chierchia R, Müller M, Santoni A, Esposito E, Mangiapane P, Scardi P, Mittiga A (2014) CZTS stoichiometry effects on the band gap energy. J Alloy Compd 582:528-534

Pan J, Liu J, Zuo S, Khan UA, Yu Y, Li B (2018) Synthesis of cuboid $\mathrm{BiOCl}$ nanosheets coupled with $\mathrm{CdS}$ quantum dots by regionselective deposition process with enhanced photocatalytic activity. Mater Lett 103:216-224

Shambharkar BH, Chowdhury AP (2016) Ethylene glycol mediated synthesis of $\mathrm{Ag}_{8} \mathrm{SnS}_{6}$ nanopartilces and their explotation in the degradation of eosin yellow and brilliant green. RSC Adv 6:10513-10519

Shambharkar BH, Chowdhury AP (2018) BiOCl- $\mathrm{Ag}_{8} \mathrm{SnS}_{6}$ heterostructure: facile preparation and photocatalytic applications. J Environ Chem Eng 6:2085-2094

Sun M, Zhao Q, Du C, Liu Z (2015) Enhanced visible light photocatalytic activity in $\mathrm{BiOCl} / \mathrm{SnO}_{2}$ : heterojunction of two wide band-gap semiconductors. RSC Adv 5:22740-22752

Sun Y, Shao C, Li X, Guo X, Zhou X, Li X, Liu Y (2018) Hierarchical heterostructures of $\mathrm{p}$-type bismuth oxychloride nanosheets on n-type zinc ferrite electrospun nanofibers with enhanced visiblelight photocatalytic activities and magnetic separation properties. J Colloid Interface Sci 516:110-120

Tana C, Zhua G, Hojamberdiev M, Okada K, Lianga J, Luo X, Liu P, Liu Y (2014) $\mathrm{Co}_{3} \mathrm{O}_{4}$ nanoparticles-loaded $\mathrm{BiOCl}$ nanoplates with the dominant 001 facets: efficient photodegradation of organic dyes under visible light. Appl Catal B Environ 152-153:425-436

Xiao P, Lou J, Zhang H, Song W, Wu X-L, Lin H, Chen J, Liu S, Wang $\mathrm{X}$ (2018) Enhanced visible-light-driven photocatalysis from $\mathrm{WS}_{2}$ quantum dots coupled to $\mathrm{BiOCl}$ nanosheets: synergistic effect and mechanism insight. Catal Sci Technol 8:201-209

Xu J-J, Yang J-W, Zhang P, Yuan Q, Zhu Y-H, Wang Y, Wu M-M, Wang Z-M, Chen M-D (2017) Preparation of 2D square-like $\mathrm{Bi}_{2} \mathrm{~S}_{3}-\mathrm{BiOCl}$ heterostructures with enhanced visible light-driven photocatalytic performance for dye pollutant degradation. Water Sci Eng 10:334-339

Yu H, Cao C, Wang X, Yu J (2017) Ag-modified BiOCl single-crystal nanosheets: the dependence of photocatalytic performance on the 
region-selective deposition of $\mathrm{Ag}$ nanoparticles. J Phys Chem C 121:13191-13201

Zang K-L, Liu C-M, Huang F-Q, Zheng C, Wang W-D (2006) Study of the electronic structure and photocatalytic activity of the $\mathrm{BiOCl}$ photocatalyst. Appl Catal B 68:125-129

Zheng Y, Zhang X, Zhao J, Yang P (2018) Assembled fabrication of $\alpha-\mathrm{Fe}_{2} \mathrm{O}_{3} / \mathrm{BiOCl}$ heterojunctions with enhanced photocatalytic performance. Appl Surf Sci 430:585-594
Zuo Y, Wang C, Sun Y, Cheng J (2015) Preparation and photocatalytic properties of $\mathrm{BiOCl} / \mathrm{Bi}_{2} \mathrm{MoO}_{6}$ composite photocatalyst. Mater Lett 139:149-152

Publisher's Note Springer Nature remains neutral with regard to jurisdictional claims in published maps and institutional affiliations. 